\title{
hitt:/www.journals.zu.edu.eg/journalDisplay.aspx?Journalld=1\&queryType=Master \\ MICROPROPAGATION OF ZAGHLOL AND BARHY DATE PALM CULTIVARS USING IMMATURE FEMALE INFLORESCENCE EXPLANTS: EFFECT OF GROWTH REGULATORS BALANCE
}

\author{
Asmaa M. Abdelaziz", S. S. A. Soliman, T. A. S. Ahmed, Ranya M. Heakal and A. A. Hassanin \\ 1. Genet. Dept., Fac. Agric., Zagazig Univ., Egypt \\ 2. Hort. Dpet., Fac. Agric., Zagazig Univ., Egypt
}

Received: 04/08/2019; Accepted: 28/08/2019

\begin{abstract}
The present study aimed to micropropagate two date palm cultivars (Zaghlol and Barhy) using immature female inflorescence and various growth regulators combinations. This experiment was done in Biotechnology Laboratory, Department of Genetics, Faculty of Agriculture Zagazig University, during three consecutive seasons 2017, 2018, and 2019. Three types of culture media were used for initiation stage, results showed that initiation medium1 $(1.0 \mathrm{mg} / 1$ 1Naphthaleneacetic acid (NAA) + $0.1 \mathrm{mg}$ Indole-3-acetic acid (IAA) + $1.0 \mathrm{mg} / 1$ 2,4Dichlorophenoxyacetic acid (2, 4-D)) was the best medium that recorded the highest callus formation rate in both Zaghlol and Barhy cultivars. But the Barhy cultivar showed higher response for callus formation than Zaghlol cultivar, especially for number of days to initiate callus (average mean 125.58 days compare to 279 days for Barhy and Zaghlol, respectively. For plant regeneration stage, it was used three plant regeneration media. Results showed that plant regeneration medium 1 (NAA $0.5 \mathrm{mg} / 1$ +benzyl adenine (BA) $2.0 \mathrm{mg} / \mathrm{l}$ ) showed the best value for each of number of leaves (19.35), leaf length $(39.75 \mathrm{~cm})$ and number of days to initiate regeneration (19). Two types of rooting media were used for root formation, it was found that rooting medium 1 (Indole-3-butyric acid (IBA) $2.0 \mathrm{mg} / \mathrm{l}+$ BA $2.0 \mathrm{mg} / \mathrm{l}$ ) gave higher response than rooting medium 2 (NAA $2.0 \mathrm{mg} / \mathrm{l}+\mathrm{BA} 2.0 \mathrm{mg} / \mathrm{l}$ ) for almost measured criteria except root length. Also, using rooting medium 1 decreased the number of days for root formation to 40 days compared to 110.25 days obtained from rooting medium 2 .
\end{abstract}

Key words: Micropropagation, Date palm, immature female inflorescence, growth regulators.

\section{INTRODUCTION}

Date Palm (Phoenix dactylifera L.) is a dioecious, perennial monocot plant species of the Arecaceae family. It is one of the most important fruit crops cultivated in arid and semi-arid regions. It is distributed throughout the Middle East and North Africa, South Sahel, areas of east and south Africa, Europe and USA (Jan, 2012), with approximately is a million trees worldwide (Al-Khayri et al, 2015).

*Corresponding author: Tel. : +201067831441

E-mail address: asmaa maher245@gmail.com
Date palm can be propagated sexually by seeds or asexually by offshoots. Propagation by seeds cannot be used for the commercial production of elite genotypes due to its heterozygous character (Tisserat, 1982), and because of the considerable difference between seedlings and vegetatively propagated plants in terms of production potential, fruit maturation and quality, and harvesting time (Zaid $\boldsymbol{e t}$ al., 2011). While using offshoots for commercial propagation facing limitation, offshoots availability and source of spreading disease in case if the offshoots taken from infected trees. 


\begin{abstract}
Abdelaziz, et al.
Usage offshoots derived explants in tissue culture of date palm have been practicing since decades. After wards, the potential of inflorescence explants have been tested to develop direct (Abul-Soad et al., 2004) and indirect somatic embryos of date palm (Drira and Al Shaary, 1993, Abul-Soad et al., 2005). Inflorescence explants have many advantages over worldwide frequently used shoot tip explants for date palm micropropagation such as: no or less bacterial contamination, no browning, short production cycle and possibility to produce rare male and elite female cultivars of date palm in case of no offshoots availability (Bhaskaran and Smith, 1992; Zaid et al., 2007; Abul-Soad and Mahdi, 2010; Jatoi, 2013).

Loutfi and Chlyah (1998) studied the vegetative multiplication of date palms from in vitro cultured inflorescence. They found that the $0.5 \mathrm{mg} / \mathrm{l} \mathrm{NAA}, 2 \mathrm{mg} / \mathrm{l} \mathrm{BA}$, and $1 \mathrm{mg} / \mathrm{l} 2 \mathrm{ip}$ consider as a better hormone balance for initiation of culture shoot multiplication occurred on the same medium, but plant growth and rooting were only obtained by a tenfold reduction in cytokinin concentration or by increase in

\section{MATERIALS AND METHODS}

\section{Plant Materials}

This experiment was carried out in Biotechnology Laboratory, Department of Genetics, Faculty of Agriculture, Zagazig University, Egypt, in three consecutive seasons 2017, 2018, and 2019, to propagate two date palm cultivars by using immature female inflorescence. Two date palm cultivars used in this study were Zaghlol and Barhy. Immature female inflorescences with 25-35 cm length of Zaghlol cultivar were obtained from Kassasen Horticulture Research Institute, in 2017, and in 2018 , with $15-20 \mathrm{~cm}$ length for Barhy cultivar.

\section{Sterilization and Preparation of Spathe and Immature Inflorescence}

First spahtes were washed under running water for $30 \mathrm{~min}$ followed by surface sterilization in $60 \%$ chlorox (5.25\% sodium hypochlorite) for $30 \mathrm{~min}$ followed by aseptically washing in sterilized distilled water for 30-60 seconds (Fig. 1) and then the protective sheath was longitudinally cut from the middle like $\mathrm{T}$ letter from one side only, Spikelet explants were cut from their base, divided to parts with 2-3 florets and cultured on initiation medium under aseptic conditions.
\end{abstract} NAA to $2.0 \mathrm{mg} / \mathrm{l}$ in combination with $1.0 \mathrm{mg} / \mathrm{l}$ 2ip on $1.0 \mathrm{mg} / \mathrm{l}$ BA Histological analysis of cultured explant, revealed that buds originated from petal premordia. Percentages of reactive inflorescence explant in various media different among examined cultivars. The technique offers great promise for vegetative propagation of date palms since several hundred plants could be obtained from a single inflorescence annually.

Many researches were done on micropropagation of date palm at commercial scale using inflorescences (Drira and Al shaary, 1993; Abahmane, 1998, 2003, 2005a, 2005b, 2010, 2011a, 2011b, 2013; Abul-Soad et al., 2005; Abul-Soad and Mahdi, 2010, Abul-Soad, 2011, 2012; Mazri and Meziani, 2013).

Therefore, the present study aimed to micropropagate two date palm cultivars with a great commercial importance Zaghlol and Barhy cultivars, using immature female inflorescence: effect of hormone balance.

\section{Media Preparation}

Inorganic macronutrient and micronutrient levels used in plant tissue culture media are based on levels established in the plant tissue culture medium developed by Murashige and Skoog (1962). Full strength $(4.4 \mathrm{~g} / \mathrm{l})$ and half strength $(2.2 \mathrm{~g} / \mathrm{l})$ Murashige and Skoog (MS) medium was used in this experiment. $30 \mathrm{~g} / \mathrm{l}$ of sucrose $(3 \%)$ was added into the medium and the growth hormones have been added as mentioned in Schedule 1 before $\mathrm{pH}$ adjustment. The $\mathrm{pH}$ of the medium was adjusted before autoclaving to $5.7 \pm 0.1$ using $0.1 \mathrm{M} \mathrm{HCl}$ and 0.1 $\mathrm{M} \mathrm{NaOH}$ followed by addition of $7 \mathrm{~g} / \mathrm{l}$ agar. Then the medium was autoclaved at $121^{\circ} \mathrm{C}$ for $20 \mathrm{~min}$. A total of $50 \mathrm{ml}$ of the sterile medium were poured into sterilized screwed jars in the laminar flow and allowed for solidification to be used.

\section{Culture Conditions}

All cultured explants were incubated in a controlled growth room at $27^{\circ} \mathrm{C}$ under full darkness. Incubated explants were re-cultured 1- 


\section{Zagazig J. Agric. Res., Vol. 46 No. (6A) 2019}

2 times; every 3-4 weeks on same initiation medium as described in Schedule 1. Wellresponded explants were transferred into initiation medium for 1-2 re-cultures. Matured and early-differentiated explants under darkness were shifted onto plant regeneration medium under illumination conditions for 1-2 recultures. Subsequently the differentiated cultures were shifted to the multiplication stage or may be the rooting stage directly (rooting medium). Well rooted plantlets were subjected to the in vitro hardening by culturing onto low nutrients medium along with more ventilation. Some date palm plantlets were successfully transplanted to the greenhouse.

\section{Data Analysis and Heritability Calculation}

The experiment was analyzed as factorial experiment design by using SPSS program to determine the significance of differences between cultivars and media. Heritability in broad sense was calculated from the following equation (Singh and Chaudhary, 1977).

$$
\begin{aligned}
& \mathbf{H}^{2}=\frac{\sigma_{\mathrm{g}}^{2}}{\sigma_{\mathrm{g}}^{2}+\sigma_{e}^{2}} \times 100 \\
& \sigma_{e}^{2}: \text { Error variance } \\
& \sigma_{g}^{2}: \text { Genetic variance }
\end{aligned}
$$

\section{RESULTS AND DISCUSSION}

\section{Initiation Stage}

Highly significant difference were recorded between the three different initiating media for callus induction frequencies, callus weight and number of days to initiate callus and subsequently the importance of hormone combination for success of obtaining induction of callus and embryonic callus (Table 1 and Fig. 2). Im1 medium $(1.0 \mathrm{mg} / \mathrm{l} \mathrm{NAA}+0.1 \mathrm{mg} / \mathrm{l} \mathrm{IAA}+1.0$ $\mathrm{mg} / \mathrm{l} 2,4-\mathrm{D})$ was the best medium that recorded the highest callus formation rate in Zaghlol cultivar (Table 2). These results confirmed the importance of 2, 4-D for callus induction and callus embryogenic. This conclusion was confirmed by the results of Jatoil, (2013) for days to initiating callus embryonic and of Othmani et al., (2010) who obtained data on embryonic callus induction of date palm $\mathrm{cv}$. Boufegous (Othmani et al., 2009). In date palm cultivars Hassan and Taha (2012) observed somatic embryos after 9 months of induction, while Eshraghi et al. (2005) suggested an induction period of 12 months for cvs. Khanizi and Monadarsive. Their findings were in agreement with our results.

\section{Multiplication (Regeneration) Stage}

For plant regeneration and multiplication, three different hormone combinations were used (PRM1, PRM2, and PRM3) for Zaghlol date palm cultivar. Highly significant differences were recorded between the three media for number of leaves, leaf length $(\mathrm{cm})$ and number of days to initiate regeneration (Table 3 and Fig. 3). These results showed the importance of using optimum hormone combinations for success of plant regeneration PRM1 (NAA 0.5 $\mathrm{mg} / \mathrm{l}+\mathrm{BA} 2.0 \mathrm{mg} / \mathrm{l}$ ) medium possessed the best value for each of number of leaves (19.35), leaf length $(39.75 \mathrm{~cm})$ and number of days to initiate regeneration (19) (Table 4).

In addition, these result illustrated the importance of low concentration of NAA $(0.5$ $\mathrm{mg} / \mathrm{l})$ for plant regeneration with BA $(2.0 \mathrm{mg} / \mathrm{l})$.

Many researches confirmed with the results of the present study. The study of Othmani $\boldsymbol{e t}$ al. (2009) was in consistence with our results in which they indicated that $1.0 \mathrm{mg} / 1 \mathrm{NAA}$ was necessary for the germination and conversion of $81 \%$ of somatic embryos into plantlets. These results confirmed that, culture media containing low ratios of Auxin/Cytokinins (NAA 0.5mg/l, BA or 2ip $2.0 \mathrm{mg} / \mathrm{l}$ ) enhance floral piece multiplication, mostly petals and usually followed by shoot formation. Explants showing petal multiplication were about $5 \%$ of the total cultured tissue. In contrast, the use of culture media with high auxins/cytokinins ratios: NAA $(0.5 \mathrm{mg} / \mathrm{l}), \mathrm{IBA}(0.5 \mathrm{mg} / \mathrm{l}) \mathrm{BA}(0.1 \mathrm{mg} / \mathrm{l})$ leads to root formation and carpel developments. The percentage of explants showing carpel development was about $30 \%$. This percentage decreased when cytokinins (BA or 2ip) concentrations were augmented (Abahmane, 2013). Earlier study by Drira and Benbadis (1985) reported that well formed plantlets can be obtained on MS medium supplemented with BA and NAA at $1.0 \mathrm{mg} / \mathrm{l}$ each, in the case of immature inflorescences, as well as, Loutfi nd Chlyah (1988) used explants from inflorescences of date palm from different female cultivars and they found that, shoot premordia formed mostly on 
Abdelaziz, et al.

Schedule 1. Composition of Nutrient media used in various stages of micro propagation

\begin{tabular}{|c|c|}
\hline Medium name/Stage & Medium composition \\
\hline \multicolumn{2}{|l|}{ Initiate medium (IM) } \\
\hline IM1 & MS+ $30 \mathrm{~g}$ sucrose +6 g agar+ 1 mg/lNAA+0.1mg/l IAA+1mg/l 2,4-D \\
\hline IM2 & $\mathrm{MS}+30 \mathrm{~g}$ sucrose $+6 \mathrm{~g}$ agar+ $1 \mathrm{mg} / 1 \mathrm{NAA}+0.1 \mathrm{mg} / \mathrm{IAA}+0.2 \mathrm{mg} / \mathrm{l} 2,4-\mathrm{D}$ \\
\hline IM3 & $\mathrm{MS}+30 \mathrm{~g}$ sucrose $+6 \mathrm{~g}$ agar+ $+0.1 \mathrm{mg} / 1 \mathrm{IAA}+0.5 \mathrm{mg} / 12,4 \mathrm{D}$ \\
\hline \multicolumn{2}{|c|}{ Plant regeneration medium (PRM) } \\
\hline PRM1 & $\mathrm{MS}+30 \mathrm{~g}$ sucrose $+6 \mathrm{~g}$ agar+ $0.5 \mathrm{mg} / \mathrm{NAA}+2 \mathrm{mg} / \mathrm{LBA}+2 \mathrm{mg} / \mathrm{l} 2 \mathrm{ip}$ \\
\hline PRM2 & $\mathrm{MS}+30 \mathrm{~g}$ sucrose $+6 \mathrm{~g}$ agar+ $0.5 \mathrm{mg} / 12,4-\mathrm{D}+0.5 \mathrm{mg} / \mathrm{NAA}+2 \mathrm{mg} / \mathrm{LBA}$ \\
\hline PRM3 & $\begin{array}{l}\text { MS+30 g sucrose +6 g agar+1 mg/l 2,4-D+0.1 mg/NAA+4mg/ LBA + 2mg/l } \\
\text { 2ip }\end{array}$ \\
\hline \multicolumn{2}{|l|}{ Rooting medium (RM) } \\
\hline RM1 & 1/2MS+ 30g sucrose +6g agar+ 2mg/LIBA+2mg/l BA \\
\hline RM2 & $1 / 2 \mathrm{MS}+30 \mathrm{~g}$ sucrose $+6 \mathrm{~g}$ agar $+2 \mathrm{mg} / \mathrm{L} \mathrm{NAA}+2 \mathrm{mg} / \mathrm{l} \mathrm{BA}$ \\
\hline
\end{tabular}

(A)
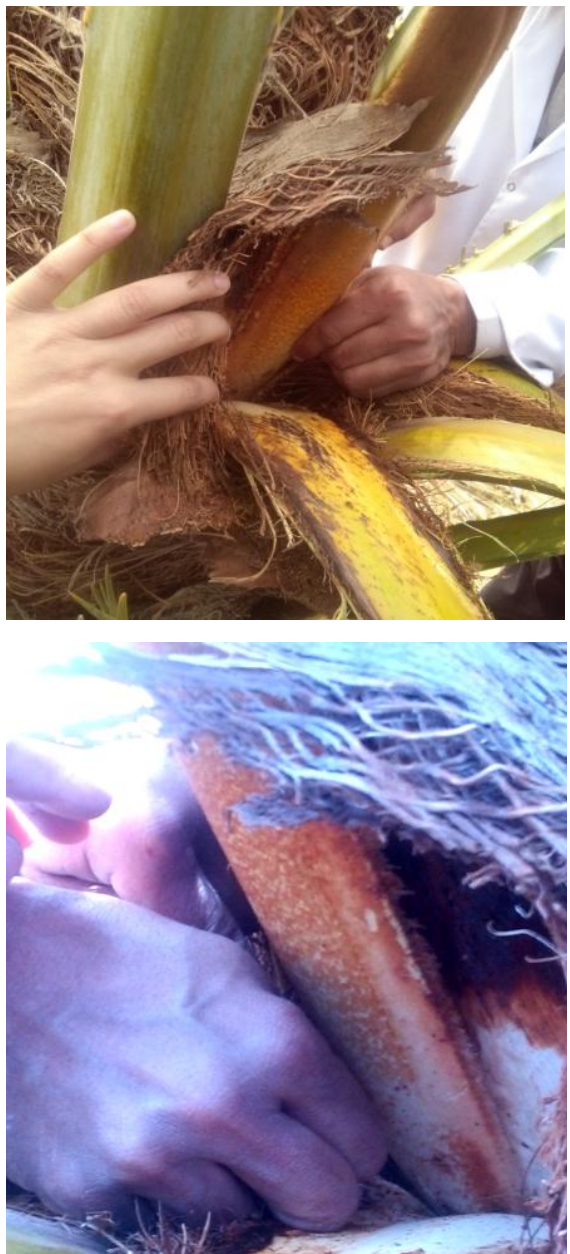

(B)
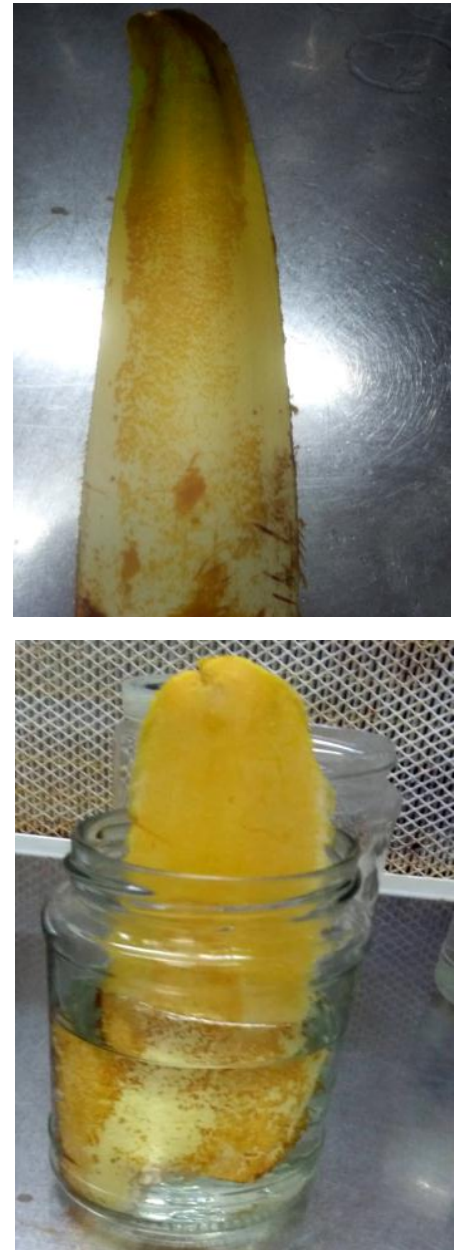

(C)
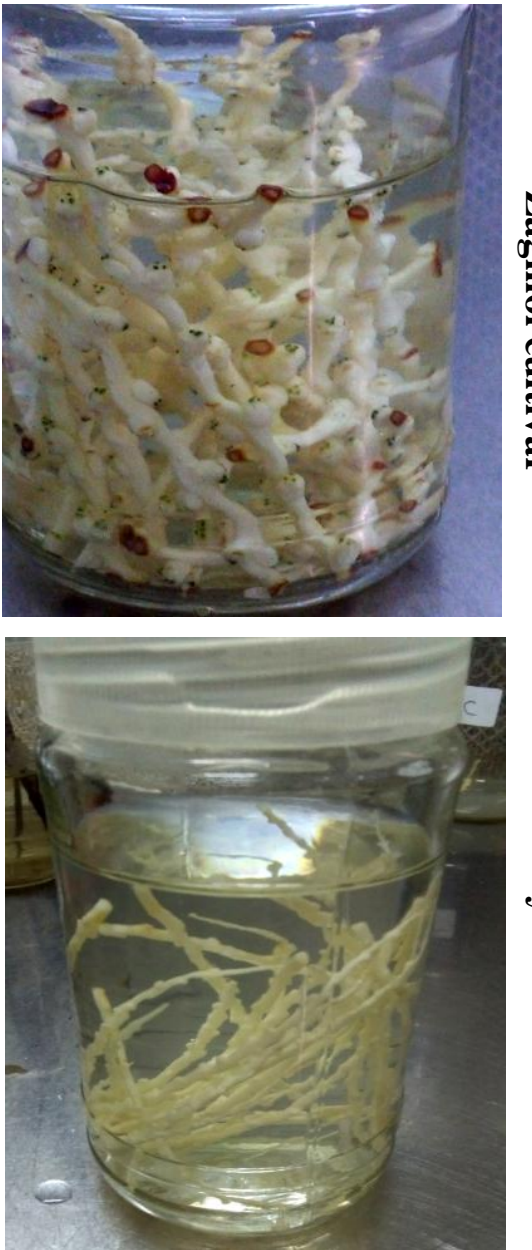

Fig. 1. Plant material used for date palm micropropagation using inflorescence tissue: (A) Spathe harvesting during flowering period (B) Spathe ready to be opened under aseptic conditions. (C) Inflorescence disinfection in sodium hypochlorite solution 
Zagazig J. Agric. Res., Vol. 46 No. (6A) 2019

Table 1. Means sum of squares (MS) of callus induction frequencies, callus weight (g) and number of days to initiate callus in Zaghlol cultivar

\begin{tabular}{lcccc}
\hline SOV & df & \multicolumn{3}{c}{ MS } \\
\cline { 3 - 5 } & & $\begin{array}{c}\text { Callus induction } \\
\text { frequencies }(\%)\end{array}$ & $\begin{array}{c}\text { Callus weight } \\
(\mathbf{g})\end{array}$ & $\begin{array}{c}\text { No. of days to } \\
\text { initiate callus }\end{array}$ \\
\hline Replicates & 3 & 1.30 & 0.48 & 16.33 \\
Treatments & 2 & $698.90^{* *}$ & $45.80^{* *}$ & $3387.5^{* *}$ \\
Error & 6 & 0.95 & 2.38 & 28.58 \\
\hline
\end{tabular}

$*=$ significant at $\mathrm{p}<0.05, * *=$ significant at $\mathrm{p}<0.01$, Values are means of four replicates.

Table 2. Average means for callus induction frequencies, callus weight (g) and number of days to initiate callus in Zaghlol cultivar

\begin{tabular}{lccc}
\hline Treatment & \multicolumn{3}{c}{ Over all means } \\
\cline { 2 - 4 } & $\begin{array}{l}\text { Callus induction } \\
\text { frequencies }(\%)\end{array}$ & $\begin{array}{c}\text { Callus weight } \\
(\mathrm{g})\end{array}$ & $\begin{array}{c}\text { No. of days to } \\
\text { initiate callus }\end{array}$ \\
\hline IM1 & 36.05 & 9.43 & 193.25 \\
IM2 & 9.87 & 3.565 & 339.75 \\
IM3 & 19.75 & 2.637 & 304.50 \\
Mean & 21.89 & 5.21 & 279.00 \\
LSD 0.05 & $\mathbf{1 . 6 8}$ & $\mathbf{2 . 6 6}$ & $\mathbf{9 . 2 2}$ \\
LSD 0.01 & $\mathbf{2 . 5 5}$ & $\mathbf{4 . 0 4}$ & $\mathbf{1 3 . 9 8}$ \\
\hline
\end{tabular}

LSD =Least significant deference.

Table 3. Means sum of squares (MS) for number of leaves/plant, leaf length (cm) and number of days to regeneration in Zaghlol cultivar

\begin{tabular}{lcccc}
\hline SOV & df & \multicolumn{3}{c}{ MS } \\
\cline { 2 - 5 } & & No. of leaves /plant & $\begin{array}{c}\text { leaf length } \\
(\mathbf{c m})\end{array}$ & $\begin{array}{c}\text { No. of days to } \\
\text { regeneration }\end{array}$ \\
\hline Replicates & 3 & 23.80 & 0.38 & 0.22 \\
Treatments & 2 & $347.12^{* *}$ & $2.56^{* *}$ & $150.58^{* *}$ \\
Error & 6 & 3.39 & 0.079 & 1.13 \\
\hline
\end{tabular}

$*=$ significant at $\mathrm{p}<0.05, * *=$ significant at $\mathrm{p}<0.01$, Values are means of four replicates. 
Abdelaziz, et al.

Table 4. Average means for number of leaves/plant, leaf length $(\mathrm{cm})$ and number of days to regeneration in Zaghlol cultivar

\begin{tabular}{lccc}
\hline Treatment & \multicolumn{3}{c}{ Over all means } \\
\cline { 2 - 4 } & $\begin{array}{c}\text { No. of leaves } \\
\text { /plant }\end{array}$ & $\begin{array}{c}\text { leaf length } \\
(\mathbf{c m})\end{array}$ & $\begin{array}{c}\text { No. of days to } \\
\text { regeneration }\end{array}$ \\
\hline PRM1 & 19.35 & 39.75 & 19.00 \\
PRM2 & 16.78 & 29.00 & 25.75 \\
PRM3 & 13.23 & 22.00 & 31.25 \\
Mean & 16.24 & 48.25 & 25.33 \\
LSD 0.05 & $\mathbf{3 . 6 0}$ & $\mathbf{0 . 5 6}$ & $\mathbf{2 . 1}$ \\
LSD 0.01 & $\mathbf{5 . 5}$ & $\mathbf{0 . 8 5}$ & $\mathbf{3 . 2}$ \\
\hline
\end{tabular}

LSD =Least significant deference.

$0.5 \mathrm{mg} / \mathrm{l} \mathrm{NAA} 2.0 \mathrm{mg} / \mathrm{l} \mathrm{BA}$ and $1.0 \mathrm{mg} / \mathrm{l} 2 \mathrm{ip}$ and the shoot multiplication occurred on the same medium.

For success and continuous of date palm micropropagation should other factors of interest of such as biotin and thiamine (Al-Khayri, 2001), coconut water (Al-Khayri, 2010), Yeast extract and casein hydrolysate (Al-Khayri, 2011), basal formation of the culture medium, silver nitrate (Al-Khayri and Al-Bahrany, 2001).

\section{Rooting Stage}

Highly significant difference between two rooting media was recorded for number of roots/ plant, root length $(\mathrm{cm})$ and number of days for root formation (Table 5). RM1 (IBA 2.0mg/l + BA $2.0 \mathrm{mg} / \mathrm{l}$ ) gave higher response than RM2 medium (NAA $2.0 \mathrm{mg} / \mathrm{l}+\mathrm{BA} 2.0 \mathrm{mg} / \mathrm{l}$ ) (Table 6 figure 4) for almost criteria except root length. Interest note, number of days for root formation decreased (40 days) for RM1 medium compared to (110.25 days) for RM2. This note confirms that IBA consider a better hormone for root formation. These results are in agreement with many other studies. Good rooting of elongated shoots was obtained on culture media containing $\mathrm{BA}$ at $\mathrm{mg} / \mathrm{l}$ and IBA at $1.0 \mathrm{mg} / \mathrm{l}$ (Drira and Benbadis, 1985). In other study, for shoot rooting (Bekheet, 2013) recommended 1.0mg/l NAA, which showed better results than IAA or IBA at the same concentration. Jatoi, (2013) reported that rooting was achieved using quarter strength MS medium containing $0.1 \mathrm{mg} / \mathrm{l}$ NAA without activated charcoal.

Regarding, Barhy cultivar was studied for callus formation for three criteria and it is found that there was highly significant difference between three media for all three studied criteria as showed with cultivar Zaghlol (Tables 7, 8 and Fig. 5), but the Barhy cultivar showed higher response for callus formation than Zaghlol cultivar, especially for number of days to initiate callus (average mean valued 125.58 days compared to 279 days for Barhy and Zaghlol (respectively). As well as the same results with Zaghlol cultivar for IM1 medium was better than other media.

Results of interaction between genotypes (Zaghlol and Barhy) and hormone balance combinations were shown in Tables 9 and 10 for callus induction frequency, callus weight and number of days to initiate callus. Highly significant differences were recorded between genotypes, media and interaction between genotypes and media for all studied criteria. These results confirmed that interaction between genotypes and different hormone balance combinations is considered a very important factor for success of date palm microprpagation. These results are in harmony with many other studies (Loutfi and Chlyah, 1998; Abahmane, 2010; Abhmane, 2011b; Abul-Soad, 2012; Abahmane, 2013). 
Zagazig J. Agric. Res., Vol. 46 No. (6A) 2019

Table 5. Means of squares (MS) for number of roots/plant, root length (cm) and number of days to initiate roots in Zaghlol cultivar

\begin{tabular}{lcccc}
\hline SOV & df & \multicolumn{3}{c}{ MS } \\
\cline { 2 - 5 } & & $\begin{array}{c}\text { No. of roots/ } \\
\text { plant }\end{array}$ & $\begin{array}{c}\text { Root length } \\
(\mathbf{c m})\end{array}$ & $\begin{array}{c}\text { No. of days for } \\
\text { root formation }\end{array}$ \\
\hline Replicates & 3 & 0.83 & 0.019 & 2503.79 \\
Treatments & 1 & $12.50^{* *}$ & $3.39^{* *}$ & $7381.125^{* *}$ \\
Error & 3 & 0.75 & 0.0003 & 0.125 \\
\hline
\end{tabular}

* =significant at $\mathrm{p}<0.05, * *=$ significant at $\mathrm{p}<0.01$.

Table 6. Average means for number of roots/plant, root length $(\mathrm{cm})$ and number of days to initiate roots in Zaghlol cultivar

\begin{tabular}{lccc}
\hline Treatment & \multicolumn{3}{c}{} \\
\cline { 2 - 4 } & $\begin{array}{c}\text { No. of roots } \\
\text { /plant }\end{array}$ & $\begin{array}{c}\text { Root length } \\
(\mathbf{c m})\end{array}$ & $\begin{array}{c}\text { No. of days for } \\
\text { root formation }\end{array}$ \\
\hline RM1 & 5.25 & 1.60 & 40.00 \\
RM2 & 2.75 & 2.90 & 101.25 \\
Mean & 4.00 & 2.25 & 70.62 \\
LSD 0.05 & $\mathbf{1 . 8 9}$ & $\mathbf{0 . 0 3 7}$ & $\mathbf{0 . 7 7 5}$ \\
LSD 0.01 & $\mathbf{3 . 5 5}$ & $\mathbf{0 . 0 7 1}$ & $\mathbf{1 . 4 5}$ \\
\hline
\end{tabular}

LSD =Least significant deference.

Table 7. Means sum of squares (MS) for callus induction frequencies, callus weight (g) and number of days to initiate callus in Barhy cultivar

\begin{tabular}{lcccc}
\hline SOV & df & \multicolumn{3}{c}{ MS } \\
\cline { 2 - 5 } & & $\begin{array}{c}\text { Callus induction } \\
\text { frequencies }(\%)\end{array}$ & $\begin{array}{c}\text { Callus weight } \\
(\mathbf{g})\end{array}$ & $\begin{array}{c}\text { No. of days to } \\
\text { initiate callus }\end{array}$ \\
\hline Replicates & 3 & 24.50 & 0.66 & 252.08 \\
Treatments & 2 & $413.50^{* *}$ & $3.818^{* *}$ & $2075.08^{* *}$ \\
Error & 6 & 2.57 & 0.105 & 0.083 \\
\hline
\end{tabular}


Abdelaziz, et al.

Table 8. Average means for callus induction frequencies, callus weight (g) and number of days to initiate callus in Barhy cultivar

\begin{tabular}{lccc}
\hline Treatment & \multicolumn{3}{c}{ Over all means } \\
\cline { 2 - 4 } & $\begin{array}{c}\text { Callus induction } \\
\text { frequencies }(\%)\end{array}$ & $\begin{array}{c}\text { Callus weight } \\
(\mathbf{g})\end{array}$ & $\begin{array}{c}\text { No. of days to } \\
\text { initiate callus }\end{array}$ \\
\hline IM1 & 63.40 & 8.52 & 130.50 \\
IM2 & 50.17 & 4.16 & 100.75 \\
IM3 & 70.20 & 5.86 & 145.50 \\
Mean & 61.25 & 6.18 & 125.58 \\
LSD 0.05 & $\mathbf{2 . 7 6}$ & $\mathbf{0 . 5 5 3}$ & $\mathbf{0 . 4 9}$ \\
LSD 0.01 & $\mathbf{4 . 1 9}$ & $\mathbf{0 . 8 4 9}$ & $\mathbf{0 . 7 5}$ \\
\hline
\end{tabular}

LSD =Least significant deference.

Table 9. Means sum of squares (MS) for callus induction frequencies, callus weight (g) and number of days to initiate callus of two cultivars (Zaghlol and Barhy)

\begin{tabular}{lcccc}
\hline SOV & df & \multicolumn{3}{c}{ Ms } \\
\cline { 3 - 5 } & & $\begin{array}{c}\text { Callus induction } \\
\text { frequencies }(\%)\end{array}$ & $\begin{array}{c}\text { Callus weight } \\
(\mathbf{g})\end{array}$ & $\begin{array}{c}\text { No. of days to } \\
\text { initiate callus }\end{array}$ \\
\hline Replicates & 3 & $17.44^{* *}$ & $0.25^{* *}$ & $184.375^{* *}$ \\
Treatments & 5 & $2299.91^{* *}$ & $29.032^{* *}$ & $38490.475^{* *}$ \\
Genotype (G) & 1 & $28743.32^{* *}$ & $130.00^{* *}$ & $70763.52^{* *}$ \\
Media (M) & 2 & $4029.48^{* *}$ & $2.83^{* *}$ & $19773.25^{* *}$ \\
G x M & 2 & $13815.25^{* *}$ & $906.33^{* *}$ & $5576.04^{* *}$ \\
Erorr & 15 & 3.70 & 0.23 & 28.275 \\
$\mathbf{H}^{\mathbf{2}}$ Broad sense & & $\mathbf{9 9 . 9 9 \%}$ & $\mathbf{9 9 . 9 \%}$ & $\mathbf{9 9 . 3 \%}$ \\
\hline$*=$ significant & & &
\end{tabular}

Table 10. Means for callus induction frequencies, callus weight ( $\mathrm{g}$ ) and number of days to initiate callus of two cultivars (Zaghlol and Barhy)

\begin{tabular}{|c|c|c|c|c|c|c|c|c|c|}
\hline \multirow{3}{*}{ Media } & \multicolumn{9}{|c|}{ Genotype } \\
\hline & \multicolumn{2}{|c|}{$\begin{array}{l}\text { Callus induction } \\
\text { frequencies }(\%)\end{array}$} & \multirow[b]{2}{*}{ Mean } & \multicolumn{2}{|c|}{ Callus weight (g) } & \multirow[b]{2}{*}{ Mean } & \multicolumn{2}{|c|}{$\begin{array}{l}\text { No. of days to } \\
\text { initiate callus }\end{array}$} & \multirow[b]{2}{*}{ Mean } \\
\hline & Zagloul & Barhy & & Zgloul & Barhy & & Zagloul & Barhy & \\
\hline M1 & 36.05 & 63.25 & 49.65 & 9.43 & 8.52 & 8.97 & 193.02 & 130.5 & 161.5 \\
\hline M2 & 9.875 & 50.175 & 30.025 & 3.26 & 4.16 & 3.71 & 339.75 & 100.7 & 220.25 \\
\hline M3 & 19.75 & 70.20 & 44.975 & 2.63 & 5.86 & 4.24 & 304.5 & 145.5 & 225 \\
\hline Means & 21.89 & 61.20 & 41.545 & 5.11 & 18.54 & 11.825 & 179.16 & 125.6 & 202.58 \\
\hline LSD\% 0.05 & & 2.85 & & & 0.722 & & & 7.8 & \\
\hline LSD\% 0.01 & & 3.99 & & & 0.997 & & & 10.9 & \\
\hline
\end{tabular}

LSD =Least significant deference. 
Zagazig J. Agric. Res., Vol. 46 No. (6A) 2019

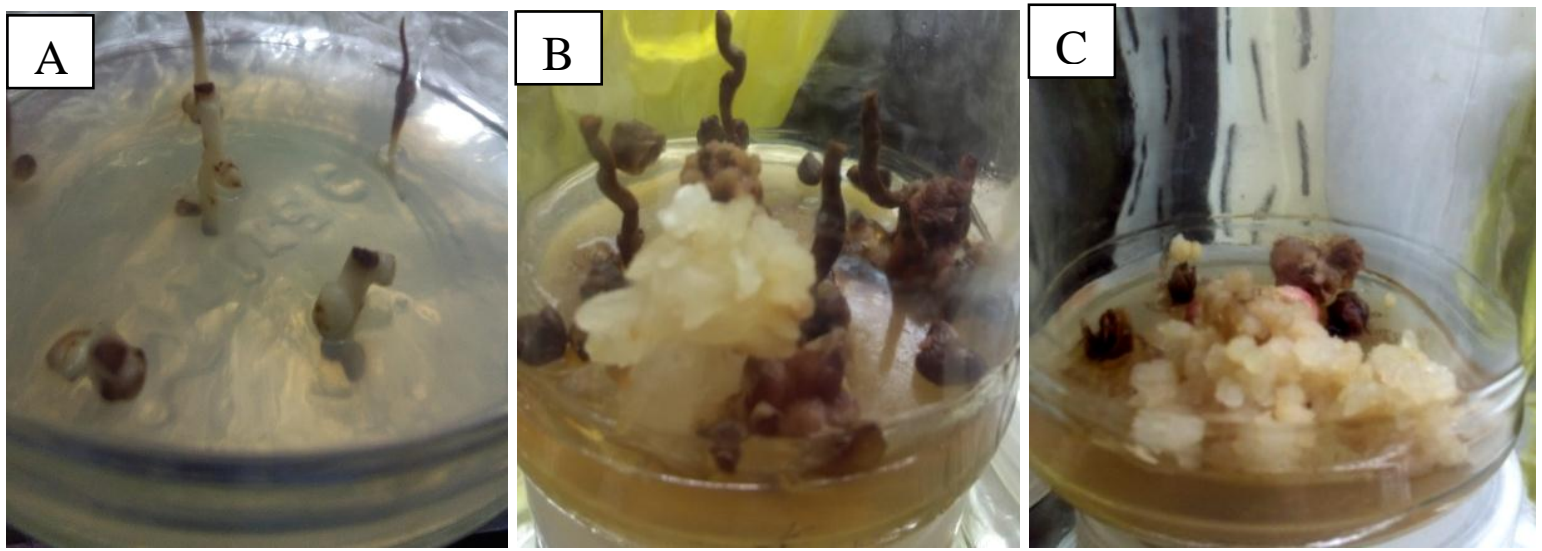

Fig. 2. Different callus formation stages of date palm micropropagation using female inflorescence explants in Zaghlol cultivar. A. Inflorescence spikelets on initiation medium. B, C. Embryogenic callus formation stage
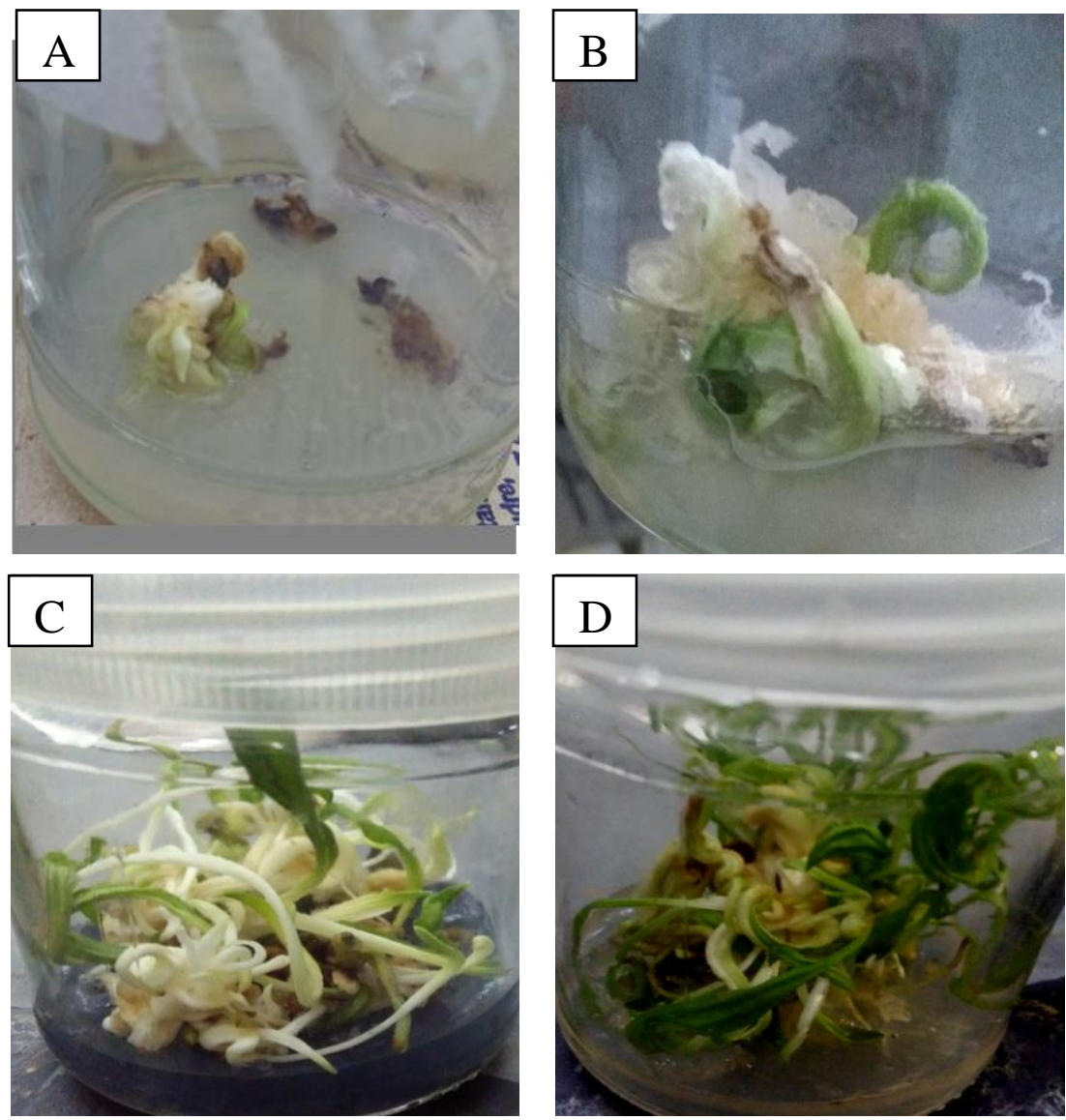

Fig. 3. Different callus formation stages of date palm micropropagation using female inflorescence explants in Zaghlol cultivar. A, B. Shoot proliferation with somatic embryos C, D. Shoots cluster on plant regeneration medium 


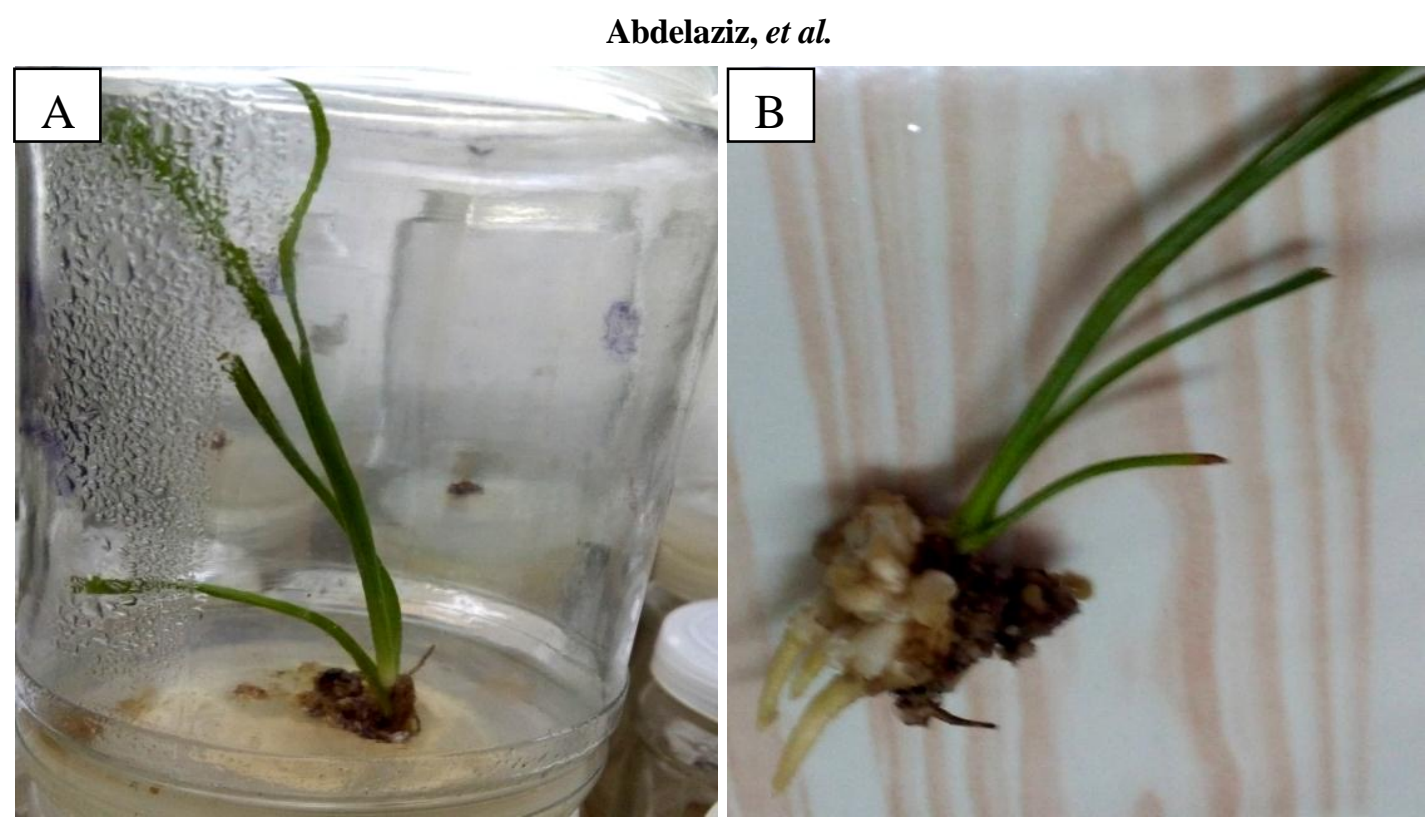

Fig. 4. A. Plantlets on rooting medium. B. Rooted plants in Zaghlol cultivar
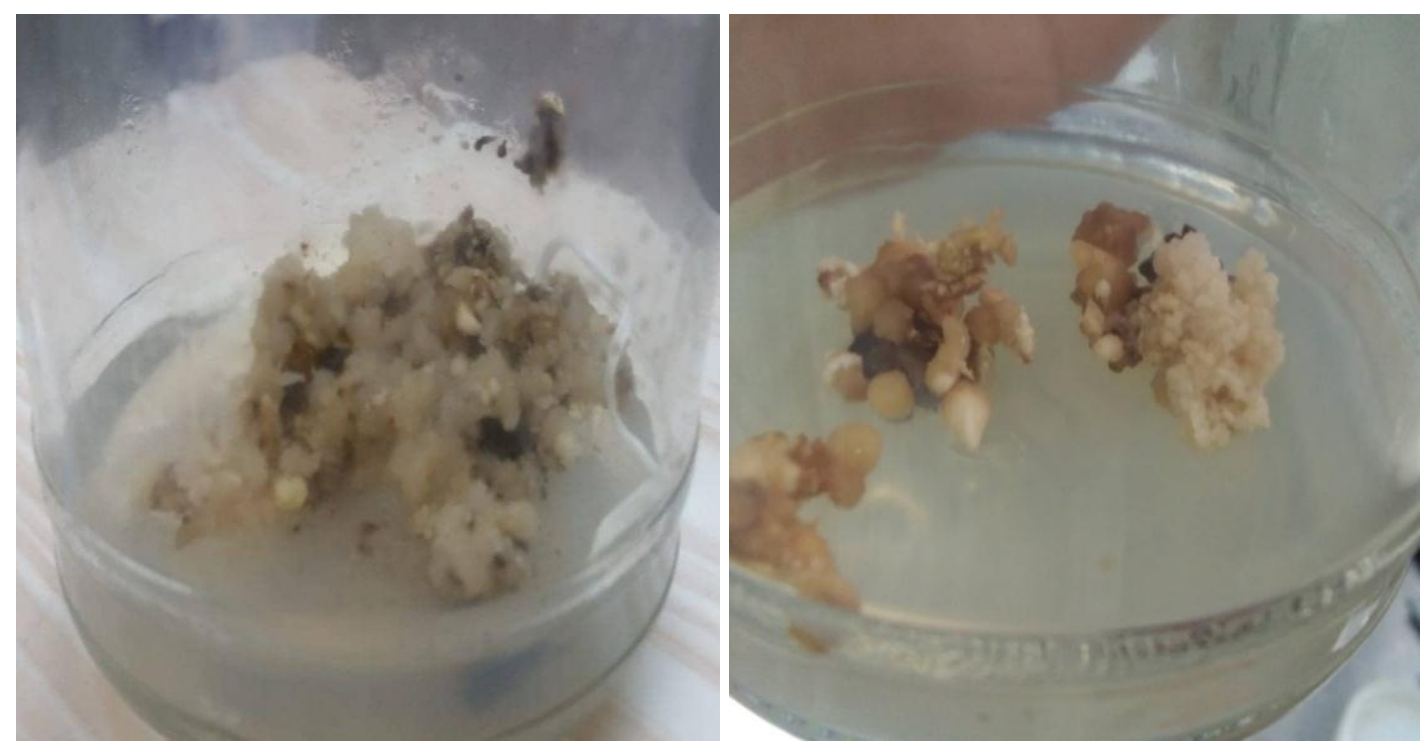

Fig. 5. Embryogenic callus formation stage in Barhy cultivar

In addition, Barhy cultivar showed higher response than Zaghlol cultivar for callus formation, which might be due to using of optimum stage of immature inflorescence or because of the different genetic background between the two cultivars.

Despite of the numerous works published on date palm micropropagation, research is still needed to optimize culture conditions for the newly selected genotypes and important cultivars to shorten the time needed to produce plantlets, and to reduce the incidence of physiological disorders.
It is also important to carry out studies related to the application of somatic embryogenesis needed for genetic transformation, synthetic seeds production and cryopreservation of embryogenic culture.

\section{Conclusion}

Based on obtained results, it could be concluded that initiation medium $1(1.0 \mathrm{mg} / 1$ $\mathrm{NAA}+0.1 \mathrm{mg} \mathrm{IAA}+1.0 \mathrm{mg} / 12$, 4-D) was the best medium that recorded the highest callus formation rate in both Zaghlol and Barhy cultivars. Plant regeneration medium 1 (NAA 


\section{Zagazig J. Agric. Res., Vol. 46 No. (6A) 2019}

$0.5 \mathrm{mg} / \mathrm{l}+\mathrm{BA} 2.0 \mathrm{mg} / \mathrm{l})$ possessed the best value for each of number of leaves (19.35), leaf length $(39.75 \mathrm{~cm})$ and number of days to initiate regeneration. Rooting medium 1 (IBA $2.0 \mathrm{mg} / \mathrm{l}+$ BA $2.0 \mathrm{mg} / \mathrm{l}$ ) gave higher response than rooting medium 2 (NAA $2.0 \mathrm{mg} / \mathrm{l}+\mathrm{BA} 2.0 \mathrm{mg} / \mathrm{l}$ ). It is important to shed light on interaction between genotypes and different hormone balance combinations as it consider very important factor for success of microprpagation of date palm.

\section{REFERENCES}

Abahmane, L. (1998). Micropropagation of date palm (Phoenix dactylifera L.) selected clones by using inflorescence tissues. In: Proc. Int. Conf. on date palm. ACSAD, Syria, 256-260.

Abahmane, L. (2003). Date palm micropropagation by using inflorescence tissues. In: Proc. Int. Symposium on Date Palm. King Saud Univ., Kingdom of Saudi.

Abahmane, L. (2005a). Les tissus inflorescentiels: Une nouvelle source de matériel végétal pour la micropropagation des clones sélectionnés du palmier dattier (Phoenix dactylifera L.). In: Proc. Int. Symposium on Sustainable Agric. Dev. Oasian Systems. Nat. Inst. Agric. Res., Morocco, 99-105.

Abahmane, L. (2005b). Micropropagation par tissus inflorescentiels du palmier dattier (Phoenix dactylifera L.): Un outil efficace pour la sauvegarde des génotypes rares. AlAwamia, 113 : 49-60.

Abahmane, L. (2010). Date palm (Phoenix dactylifera L.) micropropagation from inflorescence tissues by using somatic embryogenesis technique. Acta. Hort., 882: 827-832.

Abahmane, L. (2011a). Multiplication à partir des inflorescences: une voie prometteuse pour la micropropagation des génotypes sélectionnés de palmier dattier (Phoenix dactylifera L.). In Proc. $1^{\text {st }}$ Int. Date Palm Symposium, Algiers, 55.

Abahmane, L. (2011b). Importance of inflorescence tissues in micropropagation of selected date palm (Phonix dactylifera L.) genotypes. In: Proc. $1^{\text {st }}$ Sci. Conf. Dev. Palm and Dates Sector in Arab World, Saudi Arabia, 39.

Abahmane, L. (2013) Recent achievements in date palm (Phoenix dactylifera L.) micropropagation from inflorescence tissues. Emir. J. Food Agric., 25: 863-874.

Abul-Soad, A.A., I.A. Ibrahim, N.R. El-Sherbeny and S.I. Baker (2004). Improvement and characterization of somatic embryogenesis in date palm (Phoenix dactylifera L.). Proc. Int. Conf. Genet. Eng. and its Appl., Egypt. Soc. Genet. and Suez Canal Univ., Sharm-El Sheikh City, South Sinai, Egypt, 359-373.

Abul-Soad, A.A., N.R. El-Sherbeny and S.I. Baker (2005). Date palm (Phoenix dactylifera L. cv. Zaghloul) propagation using somatic embryogenesis of female inflorescence. Proc. $3^{\text {rd }}$ Conf. Recent Technol. Agric., Cairo Univ., Egypt, 3: 423-441.

Abul-Soad, A.A. and S.M. Mahdi (2010). Commercial production of tissue culture date palm (Phoenix dactylifera $\mathrm{L}$.) by inflorescence technique. J. Genet. Eng. Biotechnol., 8: 3944.

Abul-Soad, A.A. (2011). Micropropagation of date palm using inflorescence explants. In: S. M. Jain, J. M. Al-Khayri and D. V. Johnson (Eds.), 91-118. Date Palm Biotechnol., Springer, Dordrecht.

Abul-Soad, A.A. (2012). Influence of inflorescence explant age and 2,4-D incubation period on somatic embryogenesis of date palm. Emir. J. Food Agric., 24 (5): 434-443.

Al-Khayri, J.M. (2001) Optimization of biotin and thiamine requirements for somatic embryogenesis of date palm (Phoenix dactylifera L.). In vitro Cell. Dev. Biol. Plant, 37: 453-456.

Al-Khayri J.M. (2010) Somatic embryogenesis of date palm (Phoenix dactylifera L.) improved by coconut water. Biotechnol., 9: 477-484.

Al-Khayri J.M. (2011) Influence of yeast extract and casein hydrolysate on callus multiplication and somatic embryogenesis of date palm (Phoenix dactylifera L.) Sci Hortic., 130 : 531535. 


\section{Abdelaziz, et al.}

Al-Khayri, J.M. and A.M. Al-Bahrany (2001). Silver nitrate and 2-isopentyladenine promote somatic embryogenesis in date palm (Phoenix dactylifera L.). Sci. Hort., 89: 291-298.

Al-Khayri, J.M., S.M. Jain and D.V. Johnson (2015). Date palm genetic resources and utilization. In: Afr. and Ame., Al-Khayri JM, Jain SM, Johnson DV (eds) Springer, Dordrecht.

Bekheet, S.A. (2013). Direct organogenesis of date palm (Phoenix dactylifera L.) for propagation of true-to-type plants. Sci. Agric., 4: 85-92.

Bhaskaran, S. and R.H. Smith (1992). Somatic embryogenesis from shoot tip and immature inflorescence of Phoenix dactylifera $c v$. Barhee. Plant Cell. Rep., 12: 22-25.

Drira, N. and A. Al-Shaary (1993). Analysis of date palm female floral initials potentials by tissue culture. Third symposium on Date Palm, King Faisal Univ., Al-Hassa, Saudi Arabia, 161-170.

Drira, N. and A. Benbadis (1985). Multiplication végétative du palmier dattier (Phoenix dactylifera L.) par réversion, en culture in vitro, d'ébauches florales de pieds femelles. J. Plant Phys., 119 : 223-235.

Eshraghi, P., R. Zaghami and M. Mirabdulbaghi (2005). Somatic embryogenesis in two Iranian date palm cultivars. Afr. J. Biotechnol., 4: 1309-1312.

Hassan, M.H. and R.A. Taha (2012). Callogenesis, somatic embryogenesis and regeneration of date palm Phoenix dactylifera L. cultivars affected by carbohydrate sources. Int. J. Agric. Res., 7: 231-242.

Jain, S.M. (2012) Date palm biotechnology: Current status and prospective-an overview. Emir. J. Food Agric., 24 : 386-399.

Jatoi, M.A. (2013). In vitro rooting and acclimatization of date palm (Phoenix dactylifera L.) plantlets. M.Ph. Thesis, Dept.
Bot., Shah Abdul Latif Univ., Sindh, Khairpur, Sindh, Pak.

Loutfi, K. and H. Chlyah (1998) Vegetative multiplication of date palm from the in vitro cultured inflorescence: effect of some growth regulator combinations and organogenetic potential of various cultivars. Agron., 18: 573-580.

Mazri, M.A. and R. Meziani (2013). An improved method for micropropagation and regeneration of date palm (Phoenix dactylifera L.). J. Plant Biochem. Biotechnol., 22: 176-184.

Murashige, T. and F. Skoog (1962). A revised medium for rapid growth and bio-assays with tobacco tissue cultures. Physiologia Plantarum, 15, 473-497. http://dx.doi.org/ 10.1111 /j. 1399-3054.1962.tb08052.x.

Othmani, A., C. Bayoudh, N. Drira, M. Marrakchi and M. Trifi (2009). Somatic embryogenesis and plant regeneration in date palm Phoenix dactylifera L., cv. Boufeggous is significantly improved by fine chopping and partial desiccation of embryogenic callus. Plant Cell Tiss Organ Cult., 97: 71-79.

Othmani, A., S. Rhouma, C. Bayoudh, R. Mzid and N. Drira (2010). Regeneration and analysis of genetic stability of plantlets as revealed by RAPD and AFLP markers in date palm (Phoenix dactylifera $\mathrm{L}$.) cv. Deglet Nour. Int. Res. J. Plant Sci., 1: 48-55.

Singh, R.K. and B.D. Chaudhary (1977). Biometrical Methods in Quantitative Genetic Analysis. Kalyani Publisher.

Tisserat, B. (1982). Factors involved in the production of plantlets from date palm callus cultures. Euphytica, 31: 201-214.

Zaid, A., B. El-Korchi and H.J. Visser (2011). commercial date palm tissue culture procedures and facility establishment.

Zaid, A., H.H. Al Kaabi and B. El-Korchi (2007). Large scale in vitro propagation of a rare and unique male date palm (Phoenix dactylifera) using inflorescences technique. Acta. Hort., 736 : 243-254. 
الإكثار الدقيق لأصناف نخيل البلح (الزغلول والبارحى) باستخدام النورات المؤنثة غير الناضجة :

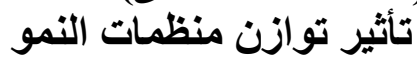

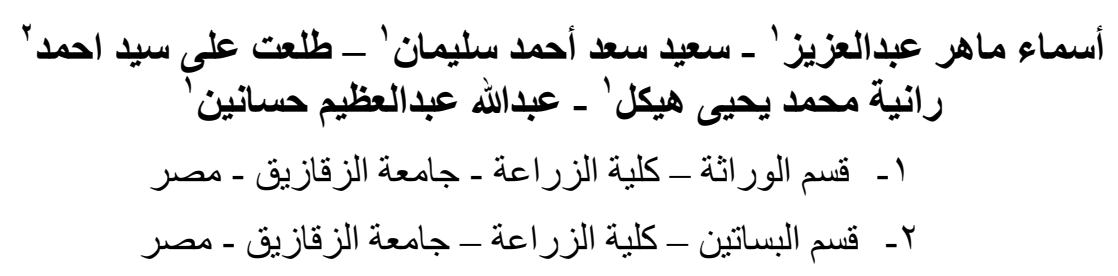

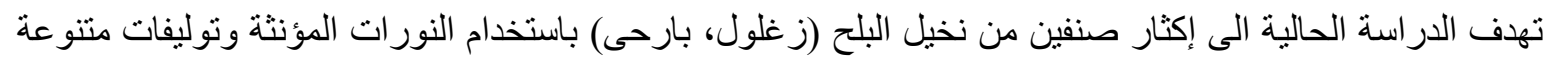

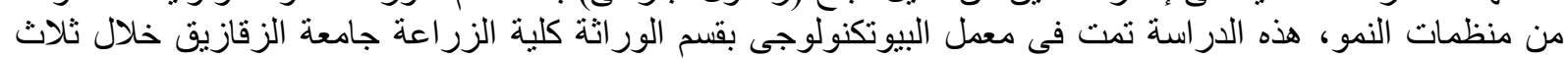

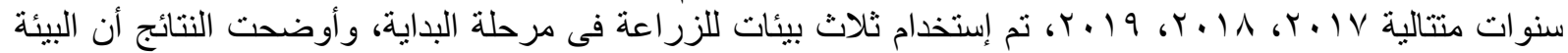

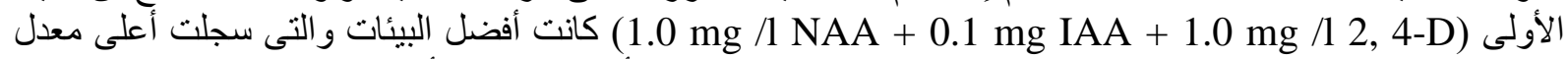

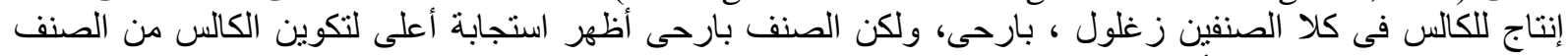

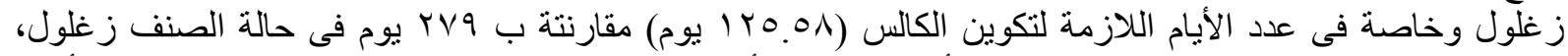

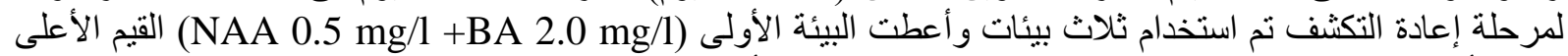

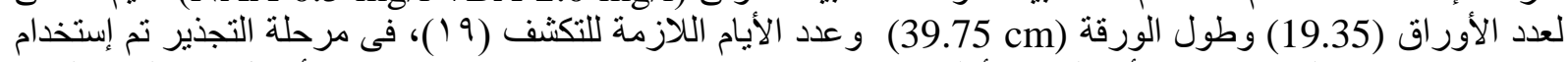

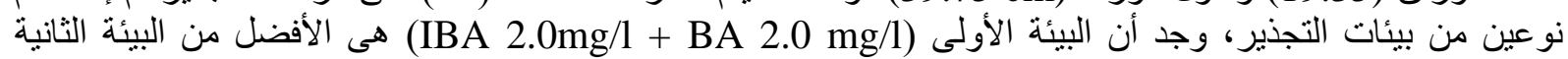

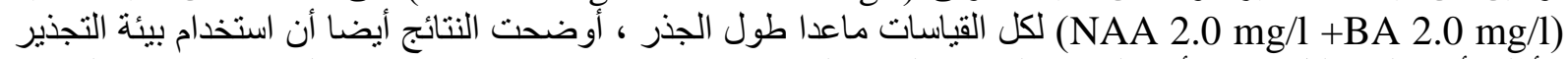

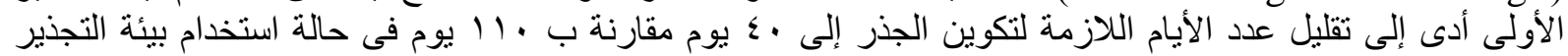
الثانية. 